\title{
MENGASAH KETERAMPILAN BAHASA ANAK USIA DINI MELALUI KEGIATAN BERNYANYI
}

\author{
Eka Rizki Amalia \\ Institut Pesantren KH Abdul Chalim \\ ekarizkiamalia2014@gmail.com \\ Hasana \\ Institut Pesantren KH Abdul Chalim \\ nurhasanasazansami300@gmail.com
}

\begin{abstract}
During the children's development, they will experience a phase called the golden age. This phase is the most crucial stage in children's development because they will grow and develop rapidly. This phase is the foundation for developing cognitive, motoric, socio-emotional, religious, moral and language abilities. Regarding the development of children's language skills, it will be optimal if it is conducted with stimulation from the surrounding both from the parents or family and the teachers. This literature study discusses the importance of directing and fostering the children's language skills from early childhood and activities that can support the stimulation process of early childhood language skills. The results of the literature review show that children's language skills must be directed and nurtured since early childhood. A person's language skills show his intelligence in expressing certain words and sentences regularly and precisely. For early childhood, the best stimulation is given by singing activities. Singing activities cannot be separated from social relations, both with the environment, society, friends, and family. By singing activities, children will be introduced to how to respect others, to put themselves in a new environment, and train their ability to communicate.
\end{abstract}

Keywords: Sharpening Language Skills, Singing, Early Childhood.

\section{Pendahuluan}

Pendidikan anak usia dini (AUD) merupakan awal dari perkembangan seorang manusia yang menempati fase utama, yang disebut sebagai golden age. Pada periode ini, hampir seluruh potensi anak bertumbuh dan berkembang secara cepat. Di masa ini anak sangat membutuhkan rangsangan atau stimulasi dari lingkungannya. Apabila anak mendapatkan stimulasi yang baik dan sesuai, ini akan berpengaruh terhadap seluruh aspek perkembangannya yang juga akan berjalan dengan baik.

Masing masing individu anak usia dini memiliki sifat, karakteristik dan keunikan tersendiri. Karakteristik dan keunikan yang dimiliki anak usia dini itulah yang membedakan mereka dengan anak-anak yang memiliki usia diatasnya, sehingga pendidikannya pun dipandang perlu dikhususkan. Pendidikan anak usia dini jelas berbeda dengan pendidikan yang lainnya. Dalam pendidikan anak usia dini, guru memfasilitasi dan mengembangkan semua aspek perkembangan anak. Anak usia dini memiliki kepekaan, keaktifan dan rasa 
ingin tahu yang besar sehingga pada masa tersebut segala potensi dan perkembangan mereka harus dioptimalkan.

Bahasa merupakan salah satu aspek penting dalam perkembangan anak usia dini. Bahasa sebagai salah satu alat komunikasi yang penting dalam kehidupan anak. Bahasa bermanfaat bagi anak untuk dapat saling berhubungan, berbagi pengalaman, dan dapat meningkatkan intelektual dalam rangka mengembangkan pengetahuan dan keterampilan bahasanya. Bagi anak yang masih dalam usia dini, masa ini harus dioptimalkan dengan dibina dan dikembangkan supaya mereka dapat maksimal dalam memanfaatkan kemampuan bahasanya. Jika bimbingan, arahan, dan penanganan yang didapat tidak tepat atau bahkan tidak diperoleh anak, sangat mungkin terjadi adanya ketidaksesuaian perkembangan bahasa mereka dengan harapan orang tua di rumah maupun oleh guru sebagai pendidik di sekolah.

Anak- anak terkadang memiliki gagasan yang banyak dan beraneka ragam, akan tetapi mereka belum mampu mengungkapkannya dengan baik. Hal itu terjadi karena jumlah kosa kata dan kemampuan bicara mereka masih sangat terbatas. Keterbatasan ini dapat disebabkan oleh kurangnya stimulasi yang diberikan oleh orang-orang yang berada dis ekitar mereka baik guru, orang tua maupun lingkungan. Jika tidak diberi stimulus dan dikembangkan maka kekurangan ini akan dapat berdampak pada perkembangan aspek- aspek lainnya.

Berkaitan dengan masa keemasan pada anak usia dini dimana anak mengalami masa perkembangan otak yang samgat pesat tidak terkecuali perkembangan bahasanya, maka dibutuhkan stimulasi dan penanganan yang tepat. Diharapkan tenaga pendidik AUD adalah guru yang professional yaitu guru dengan kompetensi dan kualifikasi yang baik dan mampu mengoptimalkan aspek- aspek perkembangan anak.

Pendidikan berfungsi untuk mencerdaskan kehidupan bangsa dan meningkatkan mutu sumber daya manusia. Untuk meningkatkan pendidikan dapat diterapkan dengan memberi pengetahuan atau yang disebut dengan pembelajaran pada kehidupan seorang manusia yang dimulai sejak dini. Pembelajaran sebagai pengetahuan yang diperoleh anak pertama kali yakni dengan memahami apa yang dilakukan maupun diucapkan oleh orang tuanya dalam bentuk tindakan maupun perkataan. Jadi anak akan secara langsung belajar melalui lingkungan sosialnya yaitu lingkungan awal dimana seorang anak berkembang. Anak akan berinteraksi dan berkomunikasi secara langsung dengan lingkungannya dalam rangka memahami dirinya sendiri dan orang lain melalui pengamatan, penglihatan, pendengaran, maupun pengalamannya sendiri. Salah sarana yang digunakan adalah melalui bahasa. Dengan demikian sangatlah jelas bahwa aspek yang paling penting dalam memepelajari suatu bahasa yakni melalui proses pembelajaran yang memerlukan dukungan dan keterlibatan langsung 
dari orang-orang yang baik secara langsung maupun tidak langsung berinteraksi dengan anak, yaitu orang tua dan guru. Pendidikan seni pada anak merupakan satu dari sekian usaha untuk menggali kemampuan dasar dan potensi anak.

Pendidikan seni memiliki banyak manfaat yang dapat diterima baik secara langsung maupun tidak langsung oleh anak. Fungsi yang dapat diterima secara langsung yakni sebagai media ekspresi diri, media komunikasi, media bermain dan media untuk menyalurkan minat dan bakat anak tersebut (Pekerti, 2008). Melalui seni, kehalusan budi anak akan dilatih karena seni dapat mengolah kepekaan anak terhadap alam sekitar dan hal- hal yang berkaitan dengan keindahan (K H Dewantoro dalam Kamaril W.S., 1998). Bernyanyi merupakan kegiatan yang dapat diintegrasikan dalam pembelajaran pada AUD. Nyanyian dan lagu dapat menghantarkan banyak pesan kepada anak- anak.

Dengan kegiatan bernyanyi, suasana belajar dapat menjadi lebih menggairahkan, menyenangkan, menggembirakan, menghilangkan rasa sedih, dan menghibur anak-anak agar lebih bersemangat. Kegiatan bernyanyi dapat mengoptimalkan fungsi otak kanan yag bertugas untuk menyimpan pesan-pesan dan input yang diterima dari luar ke dalam memori jangka panjang (long term memory) anak. Dengan demikian, anak akan selalu mengingat bahasa dan pesan-pesan yang diterimanya dalam jangka waktu yang lama.

Anak memiliki kecenderungan alami bawaan untuk bernyanyi dan bermain karena kedua aktifitas ini menyenangkan dan berperan penting dalam perkembangan mereka. Belajar dengan cara bernyanyi dapat meningkatkan kecerdasan kinestetik, hal ini dibuktikan dengan adanya peningkatan koordinasi pada tumbuh kembang anak, kelincahan dan kegembiraan (Widhianawati, 2011)

\section{Mengasah Kemampuan Bahasa Anak Usia Dini}

Perkembangan bahasa merupakan salah satu aspek pengembangan anak usia dini. Hal ini mempunyai arti bahwa aspek ini berperan penting dalam perkembangan anak serta mempengaruhi masa tumbuh kembang mereka di masa selanjutnya. Menurut Santrock (2007), bahasa (language) merupakan suatu bentuk komunikasi baik lisan, tertulis, maupun isyarat yang didasarkan pada sebuah system symbol. Bahasa terdiri atas kata- kata yang digunakan oleh masyarakat (perbendaharaan kata) dan aturan- aturan untuk memvariasikan dan mengkombinasikan kata- kata tersebut (tata bahasa dan sintaksis). Sedangkan bahasa anak usia dini yakni bahasa yang dipakai anak untuk menyampaikan pikiran, keinginan, permintaan, maupun harapan untuk dirinya sendiri. 
Kesempatan untuk memperoleh pendidikan dimulai sejak usia dini sebagai masa the golden age hingga sepanjang hayat. Dunia anak dan dunia orang dewasa sangat berbeda dalam hal karakteristiknya. Anak cenderung selalu aktif, dinamis, antusias dan memiliki keingintahuan yang besar terhadap benda-benda maupun kejadian-kejadian yang dilihat dan didengarnya seakan-akan mereka belajar tanpa henti. Anak juga memiliki memiliki beberapa sifat unik, diantaranya adalah egosentris, rasa ingin tahu secara ilmiah, merupakan makhluk sosial, unik, kaya dengan imajinasi dan fantasi, mempunyai daya konsentrasi dan perhatian yang berdurasi pendek, dan merupakan masa yang potensial untuk belajar.

Manusia selalu melakukan interaksi dengan sesamanya sesuai fitrahnya sebagai makhluk sosial. Bahasa merupakan alat untuk berinteraksi antar individu yang memegang peranan penting sejak individu masih berada pada usia dini. Bahasa dapat alat untuk komunikasi yang berupa kode-kode atau simbol-simbol yang dihantarkan untuk menyampaikan pesan, informasi maupun gagasan yang diatur menurut kaidah dan ketentuan tertentu sesuai dengan aturan di masing-masing bahasa.

Bromly di Dhieni (2005) mendefinisikan bahasa sebagai sistem simbol yang teratur untuk mentransfer berbagai ide maupun informasi yang terdiri dari simbol-simbol visual maupun verbal. Sedangkan menurut Efendi dalam Sugiarih (2010), bahasa dianggap sebagai alat- alat yang paling sempurna dan mampu membawakan pikiran dan perasaan baik mengenai hal- hal yang bersifat abstrak.

Semua anak terlahir dalam keadaan siap untuk belajar bahasa agar dapat berkomunikasi dengan orang- orang di sekitarnya. Dalam tahun- tahun pertama kehidupannya, sudah menjadi ciri khasnya bahwa dalam awal perkembangannya anak menguasai dasar-dasar dari satu bahasa. Walaupun pengembangan bahasa ini merupakan tugas yang kompleks yang membutuhkan banyak usaha, proses ini diharapkan berjalan dengan normal dan sesuai.

Seperti yang terdapat dalam permendiknas Nomor 58 tahun 2009 bahwa anak usia 4-<5 tahun mempunyai keterampilan dalam lingkup perkembangan menerima bahasa, mengungkapkan, serta keaksaraan. Dalam menerima bahasa, anak usia dini telah mampu menyimak perkataan orang lain, mengerti dua perintah, memahami cerita, serta mengenal perbendaharaan kata sifat. Sedangkan dalam hal mengungkapkan bahasa yakni berhubungan dengan keterampilan berbicara, anak usia dini telah mampu mengulang kalimat sederhana, mengungkapkan perasaan, menyebutkan kata- kata yang dikenal, mengutarakan pendapat, menyatakan alasan serta menceritakan kembali sesuatu yang ia ketahui atau yang ia dengar. Terakhir adalah dalam lingkup perkembangan keaksaraan, anak usia 4-<5 tahun telah mampu mengenal simbol- simbol, mengenal berbagai suara, membuat coretan serta menirukan huruf. 
Suharto (2005) menyebutkan bahwa berbicara dapat diartikan sebagai suatu penyampaian maksud (ide, pikiran, gagasan atau isi hati) seseorang kepada orang lain dengan menggunakan bahasa lisan sehingga maksud tersebut dapat dipahami oleh orang lain. Sedangkan menurut Abbas (2006), berbicara adalah kemampuan mengucapkan bunyi-bunyi artikulasi atau kata untuk mengeskpresikan, menyatakan serta menyampaikan pikiran, gagasan dan perasaan. Selain itu, menurut Hurlock (1978) berbicara merupakan bentuk bahasa yang menggunakan artikulasi atau kata- kata yang digunakan untuk menyampaikan maksud.

Terdapat beberapa cara dalam mengasah keterampilan bahasa anak yang dijelaskan sebagai berikut.

1. Penerapan metode bernyanyi dalam meningkatkan kecerdasan berbahasa pada pendidikan anak usia dini.

Jamalus (1998) menyebutkan bahwa "kegiatan bernyanyi merupakan kegiatan dimana kita mengeluarkan suara secara beraturan dan berirama baik diiringi oleh iringan musik ataupun tanpa iringan musik “. Bernyanyi berbeda dengan berbicara. Bernyanyi memerlukan teknik- teknik tertentu, sementara berbicara tidak memerlukan teknik khusus melainkan hanta meyampaikan maksud, gagasan atau informasi. Bagi anak, kegiatan bernyanyi merupakan kegiatan yang menyenangkan dan ada kepuasan tersendiri yang didapat dari kegiatan bernyanyi. Selain memiliki fungsi untuk meyalurkan ide dan maksud seperti kegiatan berbicara, bernyanyi juga sebagai sarana bagi anak untuk mengungkapkan pikiran dan perasaannya.

Honig dalam Masitoh dkk (2005) menyatakan bahwa bernyanyi memiliki banyak manfaat untuk praktik pendidikan anak dan pengembangan pribadinya secara luas dikarenakan beberapa hal, antara lain: bersifat menyenangkan, dapat digunakan untuk mengatasi kecemasan, merupakan media untuk mengespresikan perasaan, dapat membantu daya ingat, dapat membantu membangun rasa percaya diri anak, dapat mengembangkan rasa humor, membantu pengembangan keterampilan berfikir dan kemampuan motorik anak, dan dapat meningkatkan keeratan dalam sebuah kelompok.

Metode bernyanyi yang diterapkan mempunyai pengaruh terhadap kemampuan berbahasa anak. Tatranurandi (2018) mengungkapkan bahwa metode bernyanyi merupakan suatu metode yang melafadzkan suatu kata/ kalimat yang dinyanyikan. Beberapa manfaat metode beryanyi diantaranya yaitu membantu mencapai kemampuan dalam pengembangan daya pikir, membantu menyalurkan emosi seperti senang atau sedih melalui isi syair lagu/nyanyian, dan membantu menambah 
perbedaharaan kata baru melalui syair lagu/nyanyian (Supriadi, 2003).

Proses pembelajaran melalui metode bernyanyi telah mampu mengembangkan aspek kebahasaan anak didik dalam mengungkapkan bunyi-bunyi artikulasi atau katakata yang bertujuan untuk berkomunikasi. Kondisi seperti ini berarti bagi anak didik yang memerlukan keterampilan berbicara/berkomunikasi bertindak sebagai komunikator sebagaimana diungkapkan oleh Rabjane dalam Setiawati (2014) bahwa komunikator credible harus memiliki keahlian dan dipercaya dalam komunikasi. Rabjawe lebih jauh menyebutkan tentang prinsip SMILE yaitu komunikator harus santun, menarik, impressive, loyal dan enjoy.

2. Peran guru dalam mengembangkan kemampuan imajinasi terhadap keterampilan bercerita pada anak usia dini.

Setiap keterampilan mempunyai hubungan yang erat dengan proses- proses berfikir yang mendasari bahasa. Bahasa mencerminkan pikirannya. Semakin terampil seseorang berbahasa, semakin cerah dan jelas pula jalan pemikirannya. Keterampilan hanya dapat diperoleh dan dikuasai dengan sering melakukan praktek dan latihan yang intens.

Bercerita adalah salah satu aspek keterampilan berbahasa yang mengasah dan mengembangkan kemampuan berfikir anak. Hal ini dapat berarti bahwa bahasa merupakan kemampuan seseorang untuk menyampaikan ide, pikiran atau perasaan sehingga gagasan-gagasan yang disampaikan oleh orang yang bercerita dapat diterima dan dipahami secara baik oleh orang lain sebagai pendengar atau audiens. Berbicara mempunyai arti mengemukakan ide atau pesan secara lisan yang disampaikan secara aktif melalui kode atau lambang- lambang bunyi agar terwujud komunikasi antara penutur (pembicara) dan mitra tutur (pendengar). Setiap individu terlahir dengan kemampuan dan keterampilam berbicara dan berkomunikasi secara lisan, namun tidak semua individu memiliki keterampilan untuk berbicara secara baik dan benar.

Guru memiliki banyak peran, salah satunya yaitu menjadi penyemangat dan motivator utama dalam segala hal yang secara langsung maupun tidka langsung berkaitan dengan anak didik. Salah satu peran guru adalah menjadi perancang dan pengarah terhadap tumbuh dan berkembangnya imajinasi anak-anak dari potensi imajinatif dasar yang mereka miliki. Imajinasi merupakan alat bantu pikiran yang berfungsi untuk memahami atau menyusun sebuah ide atau konsep. Dengan demikian, imajinasi mempunyai kekuatan dan daya dorong sendiri untuk memperkuat tampilan fakta yang ada di dunia nyata menjadi gambar yang lebih menarik dan hidup layaknya 
sastra di dalam alam pikiran seseorang.

Dalam upaya mengembangkan keterampilan bercerita anak, guru dapat memilih berbagai media pembelajaran yang sesuai. Media pembelajaran dapat berfungsi untuk mengenali tipe-tipe belajar anak untuk. Secara garis besar, media dapat berupa manusia, materi atau kejadian yang membangun kondisi anak didik dalam upaya mendapatkan pengetahuan, keterampilan, maupun sikap. Dalam pengetahuan ini, guru, buku teks dan lingkungan sekolah merupakan media. Namun secara khusus, media dalam proses belajar-mengajar cenderung diartikan sebagai alat- alat grafis, photografis, atau elektronis untuk mengungkap, memproses dan menyusun kembali informasi visual atau verbal dengan lebih menarik.

3. Mengembangkan kemampuan bahasa melalui bermain kelompok

Secara teoritis permainan kelompok dapat menambah wacana dalam pegembangan kemampuan bahasa dan dapat sebagai dasar pemilihan permainan. Bermain kelompok sangat bermanfaat bagi guru dalam mengembangkan kegiatan pembelajaran terutama dalam mengembangangkan bahasa. Selain itu, permainan kelompok ini merupakan kegiatan yang sangat menyenangkan.

4. Penggunaan metode bermain permainan tradisional dalam upaya meningkatkan kemampuan berbahasa anak

Kegiatan pembelajaran dengan penggunaan metode bermain permainan tradisional, anak dapat memuaskan tuntutan dan kebutuhan perkembangan kemampuan berinteraksi, melatih kesabaran, melatih keberanian dan juga meningkatkan kemampuan bahasa anak.

5. Meningkatkan kemampuan bahasa awal anak usia dini dengan menggunakan media cerita bergambar

Metode bercerita adalah metode penyampaian atau penyajian materi pembelajaran yang dilakukan secara lisan dalam bentuk cerita atau kisah-kisah dari guru kepada anak didik. Bercerita adalah salah satu metode untuk mengasah dan meningkatkan kemampuan bahasa awal yang dapat mengembangkan beberapa aspek perkembangan anak baik fisik maupun psikis sesuai dengan tahap perkembangannya. Bercerita berfungsi untuk membantu meningkatkan kemampuan bahasa awal dan berfikir anak serta dapat memotivasi anak untuk mencintai membaca. Penggunaan metode bercerita dapat melatih berbagai kemampuan anak yang meliputi daya tangkap daya serap, daya konsentrasi, daya pikir, daya imajinasi, dan membantu perkembangan kemampuan bahasa awal anak dalam berkomunikasi. Bercerita dapat dilakukan dengan 
menggunakan berbagai alat peraga baik langsung maupun tidak langsung. Penggunaan alat peraga tak langsung seperti gambar dapat membantu fantasi dan imajinasi anak karena ada peraga pendukung yang dapat dilihat secara langsung.

6. Meningkatkan kemampuan berbicara anak melalui bermain peran mikro Dengan bermain peran mikro dapat meningkatkan kemampuan berbicara anak. Ketika anak bermain peran, pada saat itu anak akan menyampaikan atau mengucapkan yang ada dalam pikirannya. Seperti yang diungkapkan oleh Dhieni (2008), kemampuan berbicara merupakan suatau ungkapan dalam bentuk kata- kata. Selanjutnya, Arsjad dan Mukti (1998) menyatakan bahwa kemampuan berbicara adalah kemampuan mengucapkan kalimat untuk mengespresikan, menyatakan, menyampaikan pikiran, gagasan dan perasaan.

\section{Mengasah Kemampuan Bernyanyi Anak Usia Dini}

Hirmaningsih dalam Nelvalerina (2012) berpendapat bahwa ada dua bentuk kegiatan bernyanyi yang dilakukan anak, yang pertama adalah bernyanyi pasif dimana anak hanya mendengar suara nyanyian dan menikmatinya, tanpa terlibat secara langsung dalam kegiatan nyanyian. Yang kedua bernyanyi aktif, yaitu anak melakukan secara langsung kegiatan bernyanyi, baik bernyanyi sendiri, mengikuti maupun berkelompok.

Anak cenderung menyukai kegiatan yang menyenangkan bagi dirinya. Oleh karena itu, guru harus menciptakan suasana menyenangkan dalam proses pembelajaran untuk anak khususnya anak usia dini dengan strategi, metode, materi dan media menarik serta mudah diikuti anak. Bernyanyi adalah salah satu solusi yang harus diterapkan guru untuk penyampaian materi yang berkaitan dengan tujuan pengembangan anak. Melalui kegiatan bernyanyi, guru dapat lebih mudah berkomunikasi dengan anak, dan anak lebih mudah memahami serta memaknai pesan-pesan yang disampaikan guru.

Aspek- aspek pengembangan serta respon yang akan ditimbulkan secara nyata oleh anak setelah menerima pendidikan seni melalui kegiatan bernyanyi, beberapa diantaranya adalah: membentuk ekpresi dan emosi anak, pengembangan life skill anak, kemampuan berbahasa anak, dan hubungan sosial

Kegiatan bernyanyi merupakan aktifitas yang menyenangkan bagi anak yang bisa dimanfaatkan oleh para pendidik untuk menyampaikan materi. Melalui nyanyian, anak akan lebih mudah memahami dan memaknai pesan- pesan yang ingin disampaikan oleh guru. Dengan bernyanyi anak juga diberi wadah untuk mengespresikan apa yang ada dalam dirinya, apa yang dirasakan, baik itu rasa senang ataupun sedih. Anak juga dilatih untuk 
berperilaku sesuai dengan nilai- nilai norma agama, kedisiplinan, keadilan dan tanggung jawab terhadap diri sendiri dan orang lain, anak juga dilatih untuk berkomunikasi dan bersosialisasi dengan orang di sekitarnya.

Secara keseluruhan, pendidikan seni melalui kegiatan bernyanyi membawa banyak manfaat dan respond positif yang diterima oleh anak. Baik perkembangan efektif, kognitif serta psikomotor. Pendidikan hanya memiliki satu tujuan, yakni membangun generasi penerus bangsa yang dapat diandalkan untuk pembangunan negara ini dimasa yang akan datang. Tugas orang tua adalah tetap melakukan bimbingan terarah agar anak tetap pada jalan yang benar menjadi anak yang berguna dimasa depan.

\section{Penerapan metode bernyanyi untuk meningkatkan perkembangn moral anak}

Pada pembelajaran dengan menggunakan metode ini ditunjukkan kepada siswa agar dapat menyadari adanya perkembangan moral disetiap waktu dan siswa juga menyadari bahwa perkembangan moral sangat berpengaruh terhadap kehidupan sehari- harinya dimasyarakat. Seorang guru harus memiliki resolusi untuk metode pembelajaran yang digunakan disekolah seperti metode bernyanyi untuk menciptakan kelas yang menyenangkan dan tidak membosankan bagi anak dan guru juga hendaknya bekerjasama dengan orangtua dalam memfasilitasi proses belajar siswa, sehingga dapat meningkatkan kualitas pembelajaran di kelas.

\section{Studi deskriptif kegiatan pengembangan diri bernyanyi pada anak tunanetra}

Anak berkebutuhan khusus tunanetra diklasifikasikan berdasarkan kemampuan penglihatan, yakni tunanetra dengan klasifikasi buta total (blind), klasifikasi sangat berat (partiallysighted) dan klasifikasi ringan (low vision). Keadaan siswa tunanetra yang tidak dapat melihat menjadikan suatu kendala dalam menangkap materi pembelajaran baik secara teori maupun praktek. Dalam capaian tujuan pembelajaran kegiatan pengembangan diri bernyanyi, guru harus memilih metode imitasi dimana guru mencontohkan, siswa melakukan dan memakai metode drill yang dilakukan dengan mengulang-ulang lagu. Peneliti menemukan kurang maksimalnya dalam penerapan metode tersebut, hal ini bisa terlihat dalam strategi presentasi, strategi struktur, strategi pembahasan, dan analysis teknologi pembelajaran yang perlu diperbarui dan lebih kreatif karena mengingat karakteristik siswa tunanera yang khusus.

Dalam proses pembelajaran bernyanyi, siswa tunanetra harus dirangsang motivasi belajarnya dan harus memiliki suasana yang baik dalam mengikuti proses pembelajaran. Guru harus memiliki kesabaran yang baik dan metode/strategi pembelajaran yang khusus 
maupun teknik-teknik pembelajaran yang kreatif dan mengantisipasi problem tersebut, seperti halnya dengan diselingi menyanyikan lagu-lagu hiburan dan lagu favorit anak agar pelaksanaan pembelajaran tidak tegang dan lebih disukai oleh peserta didik. Hal ini erat kaitannya dalam pencapaian suatu tujuan program kegiatan pengembangan diri bernyanyi.

\section{Kesimpulan}

Aspek bahasa yang merupakan alat untuk mengekspresikan gagasan dan keinginan merupakan aspek yang penting untuk dibahas. Beberapa teori pemerolehan bahasa pada hakekatnya menunjukkan bahwa satu sama lain saling keterkaitan dan saling mendukung. Dari semua teori pemerolehan bahasa yang terpenting adalah adanya stimulasi yang dapat memunculkan dan menggali potensi yang sudah ada pada diri anak sehingga apa yang sudah ada pada diri anak tereksplor dengan baik dan apa yang belum tampak dapat ditonjolkan ke permukaan sehingga anak dapat tumbuh dan berkembang dengan baik.

Kegiatan pengembangan diri bernyanyi pada anak menjadi salah satu wadah yang disediakan sekolah untuk siswa dapat mengembangkan dan mengekspreisikan diri dalam menyalurkan minat, bakat, yang bertujuan untuk mengasah kemampuan yang mereka miliki. Secara psikologis mereka juga diarahkan untuk memiliki rasa percaya diri dan keberanian untuk berbicara dan bergerak. Dalam capaian tujuan pembelajaran kegiatan bernyanyi ini, salah satu aspek yang perlu diperhatikan yakni adanya kerjasama yang baik antara guru yang mengajar, dan elemen sekolah serta orang tua siswa dalam merangsang motivasi belajar siswa.

\section{Daftar Pustaka}

Listiyani, Anggari, dkk. (2016). Penerapan Metode Bernyanyi Untuk Meningkatkan Perkembangan Moral Anak Di TK Puspita Pandeglang.infantia. vol. 4 No 2.

Anita. (2015). Perkembangan Bahasa Anak Usia Dini. Jurnal al- shifa. Vol 06 No 02.

Azhari. (2017). Peran Guru Dalam Mengembangakan Kemampuan Imajinasi Terhadap Keterampilan Bercerita Pada Anak Usia Dini. Mahasiswa PPs UIN Ar-Raniry Banda Aceh.

Fitria, Dewi Heni. (2013). Meningkatkan Kemampuan Bahasa Awal Anak Usia Dini Melalui Media Cerita Bergambar Di RA Tarbiyatul Athfal. Jurnal Ilmiah PG_PAUD. Semarang.

Semara, Putra, dkk. (2017). Pengaruh Penerapan Metode Benyanyi Terhadap Kecerdasan Verbal Linguistic Pada Anak Kelompok B1 TK Kumara Bhuana Peguyangan Denpasar Utara. Jurnal pendidikan anak usia dini. Vol 5. No 2.

Dewi, Rahmayanti Siti dkk. (2017). Pengaruh Metode Pembelajaran Bernyanyi Terhadap Pelaksanaan Cuci Tangan Pada Anak Usia Prasekolah Di RA Baiturrahim Cibeber 
Cimahi Tahun 2017. Jurnal Kesehatan Kartika, vol.12 No 2.

Risky, Ramadani. (2014). Meningkatkan Keterampilan Berbicara Melalui Metode BercakapCakap Dengan Media Gambar Pada Anak Kelompok B2 Di TK 'Aisyah Randubelang. Fakultas Ilmu Pendidikan. Universitas Negeri Yogyakarta.

Zaina, Riansyah dkk. (2018). Studi Deskriptif Kegiatan Pengembangan Diri Bernyanyi Pada Anak Tunanetra Di Sekolah Luar Biasa Wacana Asih Kota Padang. Jurnal Sendratsik. Vol.7 No 1.

Santrock, John W. (2007). Perkembangan Anak. Jilid I Edisi 11. Jakarta: PT. Erlangga.

Suryaningsih. (2016). Pengaruh Metode Bernyanyi Terhadap Perkembangan Bahasa Anak Usia Dini Di Lembaga Paud Melati II Madiun. Prosiding Seminar Nasional Pendidikan. Program studi PG PAUD, IKIP PGRI madiun, Indonesia.

Olva, Susanti Yumi. (2017). Meningkatkan Kemampuan Berbicara Anak Melalui Bermain Peran Makro. Jurnal PG-PAUD FKIP UNIB. Vol 2 No 1.

Susilawati. (2014). Penerapan Metode Bernyanyi Dalam Meningkatkan Kecerdasan Berbahasa Pada Pendidikan Anak Usia Dini (Studi Deskriptif Tentang Penerapan Metoda Bernyanyi Di PAUD Alazhar Syfa Budi Parahyangan). Jurnal EMPOWERMENT. Vol 4 No 2.

Made, Sutama. (2014). Penggunaan Metode Bermain Permainan Tradisional Dalam Upaya Meningkatkan Kemamuan Berbahasa Dan Sosial Emosional Anak Kelompok B TK Sebana Sari.e- journal Program Pascasarjana UPG. Vol 4 tahun 2014.

Nelvalerina, Tiurma. (2012). Pendidikan Seni Melalui Kegiatan Bernyanyi Pada Anak Usia Dini. Jurnal Pendidikan Sendratasik. Fakultas Bahasa dan Seni. Universitas negeri Surabaya

Undayani. (2013). Upaya Pengembangan Kemampuan Bahasa Melalui Bermain Kelompok Pada Anak Kelompok B TK Pertiwi Ngolondono I Karangdowo Klaten. Fakultas Keguruan dan Ilmu Pendidikan. Universitas Muhammadiyah Surakarta.

Wagiyanti. (2014). Upaya Meningkatkan Kemampuan Bernyanyi Melalui Media Audio Pda Anak Kelomok B TK Pertiwi 1 Sambi Sambirejo Sragen. Fakultas Keguruan dan Ilmu Pendidikan. Universitas muhammadiyah Surakarta. 